\title{
Comparison of Eight Weeks Rhythmic Gymnastics, Pilates and Combined Training in Terms of Some Physical, Physiological and Motoric Parameters
}

\author{
Sezen Çimen Polat ${ }^{*}$, Mehmet Günay \\ Sport Sciences Faculty, Gazi University, Turkey
}

Copyright $(2016$ by authors, all rights reserved. Authors agree that this article remains permanently open access under the terms of the Creative Commons Attribution License 4.0 International License

\begin{abstract}
A long and hard preparation process to improve motoric characteristics and technical requirements is needed for rhythmic gymnasts to become a competitor. Studies show that positive effects of pilates on body, resemble the effects of rhythmic gymnastics. This study is based on the idea that the preparation period for long rhythmic gymnastics training could be shortened by the support of pilates exercises. Additionally, comparing some physical, motor and physiological parameters of rhythmic gymnasts who had just started training either for rhythmic gymnastics, pilates [mat series] or combined [rhythmic gymnastics + pilates] for 8 weeks. 30 girl gymnasts whose average ages are $7,30 \pm 1,41$ years participated to the study. As the measurements and interpretations are based on little girls at the age of 7, all the families' approvals have been received before the study. Flamingo balance test, plate tapping, standing broad jump, sit-up test for 30 seconds, sit and reach flexibility test, bent arm hang, 10x5 m running and shuttle running test were performed pre and post training. Visual and auditory reaction and hand grip strength measurements were also included. Data analysis is conducted in SPSS 22.0 software package. Pre and posttest parameters were compared with Anova and Kruskall Wallis tests for significance and distribution of the data was tested with Shapiro-Wilk test. Significant development was observed for visual and auditory reaction, tapping plate, standing broad jump, 30 second sit-up test, sit and reach flexibility test, bent arm hang, $10 \times 5 \mathrm{~m}$ running in pilates training group; auditory reaction, $30 \mathrm{sec}$ sit-up, sit and reach flexibility in rhythmic gymnastics and pilates + rhythmic training groups. The results showed that rhythmic gymnastics training accompanied by pilates are more beneficial for the fundamental level girl gymnasts.
\end{abstract}

Keywords Rhythmic Gymnastics, Pilates, Eurofit Test

\section{Introduction}

Rhythmic gymnastics is an artistic and aesthetical sport which requires very intensive training, technical movements at a high level, more repetition and different abilities. Gymnasts also need to train every day of the week that starts at a very young age because of the bone maturation [1]. Flexibility, strength, endurance, coordination, agility, balances and rhythm is necessary to develop motor skills at a high level. In addition, flexibility and strength plays an important role in rhythmic gymnastics. Good interaction between flexibility and strength is recommended for highquality performance. Laffranch [1996] states that high performance is achieved through further planning and organized training [2]. Long and heavy training programs require gymnasts to have endurance in force production in rhythmic gymnastics. Agility is a necessity for good and correct execution of a performance in rhythmic gymnastics according to movement, rhythm and tempo. Agility could be trained by the speed of the movement and adaptation to various rhythms for rhythmic gymnastics at different levels. In addition, tools and methods such as music and dance should be used in order to develop elements like internal perception and creativity and these should be developed together with the conditional practices [3]. Rope, ball, hoop, clubs and ribbon should also accompany to the said practice [2]. In addition to this, competitions also require a high level of physical and psychological toleration. The development of good gymnasts requires specific information. As a very comprehensive sport, rhythmic gymnastics requires extensive content of training and a long preparation period [4]. Gymnastics is a sport that needs trainings to begin at a very early age. As mentioned above, it takes years of a gymnast to be a competitor as it is necessary to develop all motoric characteristics at the best level. 
Pilates was invented in 1920 by Joseph Pilates who was born in 1880 in Germany near Dusseldorf. Pilates is the system of physical exercises aiming first to increase flexibility and strength of the body [5]. Pilates was more interested in body and mind connection by believing that a healthy person aims to have a strong mind and this strong mind needs to be used in order to control the physical body. It has created a whole new technique by combining physicalism of gymnastics and other sports together with a special breathing technique [6]. Posture and balance can be developed [7]. Alongside the effects of pilates based exercises on muscle activation, also the effects on motoric parameters such as flexibility and balance have been analyzed in many different studies. Anderson [2000] mentions that pilates exercises ensure to improve balance that helps development of athletic performance. [8]. Pilates exercise method has been used frequently in recent years, in sport branches where flexibility and balance are the fundamental supporter of the sportive performance. Studies regarding these sports branches reveal that pilates exercise method has positive effects on increasing the sportive performance. For example, in a study which was conducted by Bertolli et al. [2007], the effects of pilates method on flexibility of posterior thigh muscles on futsal players are examined and increase in the flexibility values of players under the age of 20 is observed [6]. Studies reveal improvement on flexibility, strength and endurance and also show that pilates improves posture, slows down aging and improves life quality [7]. A long and hard preparation process to improve motoric characteristics and technical requirements is needed for rhythmic gymnasts to become a competitor. Studies show that positive effects of pilates on body, resemble the effects of rhythmic gymnastics. Starting from this point of view, it is assumed that exercising pilates trainings together with rhythmic gymnastics can contribute to the improvement of performance of the gymnasts and shorten the preparation process to become a competitor. This study aimed to analyze this and answer the quesiton whether pilates has such an effect or not. The purpose of the study is to compare the 8 weeks long rhythmic gymnastics, pilates [mat series] and combined [rhythmic gymnastics + mat series] trainings of fundamental level rhythmic gymnasts in terms of some physical, motoric and physiological characteristics.

\section{Materials and Methods}

The study is conducted in a rhythmic gymnastics club in Ankara, with 30 fundamental level gymnasts, at the average age of 7,30 $\pm 1,41$ years, the body height of $10 \pm 8,52 \mathrm{~cm}$ and the body weight of 19,85 $\pm 3,69 \mathrm{~kg}$. Gymnasts are separated to three groups of 10 by random selection. First group practiced usual rhythmic gymnastics trainings of 90 minutes, twice a week, and second group practiced 90 minutes of only pilates mat series, twice a week, third group practiced 45 minutes of rhythmic gymnastics trainings and also 45 minutes of pilates mat series in their 90 minutes long training sessions, twice a week. The contents of the trainings are the same; however, the number of repetitions is arranged according to the duration of the trainings. "Eurofit Physical Ability Test" is applied to the subjects before and after the 8 weeks long trainings. Measurements are taken after a 10 minutes of warming-up exercise session and taken during 2 weeks a time. As the measurements and interpretations are based on little girls at the age of 7, all the families' approvals have been received before the study. Rhythmic gymnastics training program, exercises executed in pilates training program and some exercises table of figures executed in pilates training program are given in appendix.

\section{Performance Tests}

Hand Grip Strength: The subject holds the dynamometer in the hand to be tested. When ready the subject squeezes the dynamometer with maximum isometric effort, which is maintained for about 5 seconds. Best result of two trials is recorded [8].

Flamingo Balance Test: The subjects stand on a beam with the length of $50 \mathrm{~cm}$, the body height of $4 \mathrm{~cm}$, the width of $3 \mathrm{~cm}$ and try to stand in balance for 1 minute. While balancing on the preferred leg, the free leg is flexed at the knee and the foot of this leg held close to the buttocks. Instructor stops the stopwatch each time the person loses balance. Every time the subject loses balance the test is stopped [9].

Plate Tapping Test: Two discs are placed with their centers $60 \mathrm{~cm}$ apart on the table. The rectangle is placed equidistant between both discs. The non-preferred hand is placed on the rectangle. The subject moves the preferred hand back and forth between the discs over the hand in the middle as quickly as possible. This action is repeated for 25 full cycles and recorded in terms of seconds [10].

Standing Broad Jump: The athlete stands behind a line marked on the ground with feet slightly apart. A two foot take-off and landing is used, with swinging of the arms and bending of the knees to provide forward drive. The subject attempts to jump as far as possible, landing on both feet without falling backwards. The maximum distance is recorded as meters $[13,11]$.

30 Seconds Sit-Up Test: The aim of this test is to perform as many sit-ups as one can in 30 seconds. Subjects lie on the mat with the knees bent at right angles, with the feet flat on the floor and held down by instructor. The fingers are to be interlocked behind the head and raise the chest so that the upper body is vertical, then return to the floor. The maximum number of correctly performed sit-up test for 30 seconds is recorded [9].

Reaction Test: Reaction time is saved as visual and auditory reaction by New Test with dominant hand. The best result of three trials is recorded [12].

Sit and Reach Flexibility Test: This test involves sitting on the floor with legs stretched out straight ahead. The soles 
of the feet are placed flat against the box. Both knees should be locked and pressed flat to the floor - the instructor may assist by holding them down. With the palms facing downwards, and the hands on top of each other or side by side, the subject reaches forward along the measuring line as far as possible. Best result of two trials is recorded [13].

Bent Arm Hang: The subject is assisted into position, the body lifted to a body height so that the chin is level with the horizontal bar. The bar is grasped using an overhand grip with the hands shoulder width apart. The timing starts when the subject is released. They should attempt to hold this position for as long as possible. Timing stops when the person's chin falls below the level of the bar or the head is tilted backward to enable the chin to stay level with the bar [9].

10x5 m Run Test: Marker lines are placed five meters apart. Start with a foot at one marker. When instructed by the timer, the subject runs to the opposite marker, turns and returns to the starting line. This is repeated five times without stopping [14].

Shuttle Run Test: This test involves continuous running between two lines $20 \mathrm{~m}$ apart in time to recorded beeps. The subjects stand behind one of the lines facing the second line, and begin running when instructed by the recording. The test is stopped if the subject fails to reach the line for two consecutive ends after a warning [15].

Statistical Analysis: Data analysis is performed by SPSS 22.0 software package. Descriptive statistics are shown as mean \pm standard deviation for continuous and discrete numeric variables. To investigate whether the change in training variables is different or not, measured values before training is subtracted from measured values after training and the amount of change [increase or decrease] is analyzed. Shapiro-Wilk test is used to analyze whether the variables are normally distributed or not. If the categories of variables distributed normally at the same time, ANOVA is performed. If the results of ANOVA do not have homogeneous variance according to Levene test results, Kruskal Wallis test in used instead of ANOVA. Comparison of independent variables with two categories which are normally distributed is performed by $\mathrm{t}$ test. $\mathrm{T}$ test is also used for comparison of dependent variables for dependent observations. Test statistics are preferred according to the results of Levene test performed for the homogeneity of variances. Mann-Whitney test which is a non-parametric method is used to compare independent numeric variables, which are not distributed normally. Also, Wilcoxon test which is a non-parametric method is used to compare dependent numerical variables. Unless stated otherwise the results as $p<0,05$ is considered statistically significant.

\section{Result}

In the study, significant differences observed in plate tapping, standing broad jump, 30 second sit-up test, 10x5 m run, sit and reach flexibility and bent arm hang parameters after trainings at the pilates training group. The study also determined significant improvements after trainings in 30 second sit-up test and sit and reach flexibility parameters at rhythmic gymnastics training group and rhythmic gymnastics + pilates training group. In this study there were not any significant differences in visual and auditory reaction, plate tapping, standing broad jump and 10x5 m running among the pilates, rhythmic gymnastics and rhythmic gymnastics + pilates training groups.

\section{Discussion}

While heart rate only shows a significant decrease in pilates training group, there is no significant change in the groups in terms of systolic and diastolic blood pressure. The reason is, training programs are not programs that can show cardiovascular effects and subjects are at developmental age.

In the study, there is no significant change in body height in all three training groups before or after the trainings. Body height is determined as $120,90 \pm 7,80 \mathrm{~cm}$ before training and as $112,00 \pm 7,16 \mathrm{~cm}$ after training in pilates training group, as $116,80 \pm 9,81 \mathrm{~cm}$ before training and as $117,40 \pm 10,20 \mathrm{~cm}$ after training in rhythmic gymnastics training group and as $119,60 \pm 8,18 \mathrm{~cm}$ before training and as $119,60 \pm 7,60 \mathrm{~cm}$ after training in pilates + gymnastics group. Bağc1 [2003] found the average body height of rhythmic gymnasts at the age of 9-11 as $136.72 \mathrm{~cm}$, Kankal [2008] found the average body height of rhythmic gymnasts at the average age of $6,5 \pm 1,01$ years as $135,07 \pm 3,87 \mathrm{~cm}$. Đorđević et al [2014] found the average body height of rhythmic gymnasts at the age of 7 as $125.41 \pm 5.9 \mathrm{~cm}$ $[16,17,18]$. The short body heights encountered in the study is supposed to be stemming from the selection of athletes.

While body weight and body fat percentage show significant improvement in the groups which practised rhythmic gymnastics and pilates training programs, while there is no change in the group which practised pilates + gymnastics training program. Increases in body weight and body fat percentage in rhythmic gymnastics and pilates training groups may be the related to the reason that gymnasts are at the developmental age and also no change in the pilates + gymnastics group may be related to the effect of the training program. Kankal [2008] calculated the weight of rhythmic gymnasts at the age of $10,14 \pm 0,44$ as $27,86 \pm 2,62 \mathrm{~kg}$, also Đorđević et al [2014] calculated body mass as $25.27 \pm 3.0 \mathrm{~kg}[18,17]$. It is indicated that compared to the other girls, age of menarche is older, the body fat, body height and body weight are lesser in rhythmic gymnasts [19]. The results of the study also support these findings. Alexander [1991] mentions that less body fat percentage is important in terms of aesthetics and body fat percentage is expected to be $11,24-19,35 \%$ in rhythmic gymnastics [18]. Case et al [1979] figured out that rhythmic gymnasts have much lesser body fat percentage than the sedentary women [20]. 
Physical, Physiological and Motoric Parameters

Table 1. Pre and post training test scores of groups.

\begin{tabular}{|c|c|c|c|c|c|c|c|}
\hline Parameter & Group & $\begin{array}{l}\text { Pre-Training } \\
\text { Program }\end{array}$ & $\begin{array}{l}\text { Post-Training } \\
\text { Program }\end{array}$ & $\begin{array}{c}\text { Change } \\
{[\%]}\end{array}$ & $\mathrm{T}$ & $\begin{array}{c}\text { Pre-Training } \\
\text { Program Comp. } \\
\text { of Groups }\end{array}$ & $\begin{array}{c}\text { Post-Training } \\
\text { Program } \\
\text { Comp. of Groups }\end{array}$ \\
\hline \multirow{3}{*}{$\begin{array}{c}\mathrm{KAH} \\
\text { [beat/min.] }\end{array}$} & PL & $98,30 \pm 10,47$ & $93,70 \pm 11,23^{a}$ & $-4,68$ & $-1,48$ & \multirow{3}{*}{4,41} & \multirow{3}{*}{$4,07 *$} \\
\hline & $\mathrm{RC}$ & $103,0 \pm 16,28$ & $103,40 \pm 17,3^{\mathrm{b}}$ & 0,38 & $-0,09$ & & \\
\hline & $\mathrm{PL}+\mathrm{RC}$ & $110,60 \pm 9,18$ & $110,40 \pm 9,41^{\mathrm{b}}$ & $-0,19$ & 0,146 & & \\
\hline \multirow{3}{*}{$\begin{array}{c}\mathrm{SKB} \\
{[\mathrm{mmHg}]}\end{array}$} & PL & $100,40 \pm 1,95$ & $100,20 \pm 1,13$ & $-1,93$ & 0,452 & \multirow{3}{*}{0,98} & \multirow{3}{*}{0,33} \\
\hline & $\mathrm{RC}$ & $99,50 \pm 1,90$ & $100,00 \pm 0,81$ & 5,26 & $-0,68$ & & \\
\hline & $\mathrm{PL}+\mathrm{RC}$ & $90,20 \pm 2,09$ & $100,40 \pm 2,31$ & 13,04 & $-1,480$ & & \\
\hline \multirow{3}{*}{$\begin{array}{c}\mathrm{DKB} \\
{[\mathrm{mmHg}]}\end{array}$} & PL & $60,40 \pm 0,96$ & $60,10 \pm 1.10$ & $-4,69$ & $-0,72$ & \multirow{3}{*}{2,28} & \multirow{3}{*}{2,82} \\
\hline & $\mathrm{RC}$ & $50,70 \pm 1,33$ & $50,30 \pm 1.05$ & $-7,02$ & 1,50 & & \\
\hline & $\mathrm{PL}+\mathrm{RC}$ & $50,30 \pm 1,160$ & $60,00 \pm 1,33$ & 13,20 & $-1,56$ & & \\
\hline \multirow{3}{*}{$\begin{array}{c}\text { Body Weight } \\
{[\mathrm{kg}]}\end{array}$} & PL & $19,49 \pm 2,65$ & $20,53 \pm 2,98$ & 5,33 & $-4,76^{*}$ & \multirow{3}{*}{2,63} & \multirow{3}{*}{1,48} \\
\hline & $\mathrm{RC}$ & $18,26 \pm 3,85$ & $19,56 \pm 4,26$ & 7,11 & $-2,80^{*}$ & & \\
\hline & $\mathrm{PL}+\mathrm{RC}$ & $21,80 \pm 3,84$ & $21,59 \pm 3,86$ & $-0,97$ & 0,35 & & \\
\hline \multirow{3}{*}{$\begin{array}{l}\text { Body Height } \\
{[\mathrm{cm}]}\end{array}$} & PL & $120,90 \pm 7,80$ & $122,00 \pm 7,16$ & 0,90 & $-1,81$ & \multirow{3}{*}{0,58} & \multirow{3}{*}{0,74} \\
\hline & $\mathrm{RC}$ & $116,80 \pm 9,81$ & $117,40 \pm 10,20$ & 0,51 & $-1,32$ & & \\
\hline & $\mathrm{PL}+\mathrm{RC}$ & $119,60 \pm 8,18$ & $119,60 \pm 7,60$ & 0 & 0,00 & & \\
\hline \multirow{3}{*}{$\begin{array}{c}\text { BMI } \\
{\left[\mathrm{kg} / \mathrm{cm}^{2}\right]}\end{array}$} & PL & $13,30 \pm 1,21^{\mathrm{a}}$ & $12,62 \pm 4,60$ & $-5,12$ & $-1,37$ & & \\
\hline & $\mathrm{RC}$ & $13,26 \pm 1,14^{\mathrm{a}}$ & $14,05 \pm 1,07$ & 5,95 & $-3,59 *$ & $8,38^{*}$ & 2,50 \\
\hline & $\mathrm{PL}+\mathrm{RC}$ & $15,10 \pm 1,05^{\mathrm{b}}$ & $15,03 \pm 1,37$ & $-0,47$ & 0,22 & & \\
\hline & PL & $17,53 \pm 2,36^{\mathrm{a}}$ & $18,43 \pm 2,71$ & 5,13 & $-2,33^{*}$ & & \\
\hline Body Fat \% & $\mathrm{RC}$ & $16,74 \pm 1,99^{\mathrm{a}}$ & $18,60 \pm 2,34$ & 11,11 & $-4,90 *$ & $4,81^{*}$ & 0,77 \\
\hline & $\mathrm{PL}+\mathrm{RC}$ & $19,87 \pm 2,62^{b}$ & $19,72 \pm 2,48$ & $-0,76$ & 0,19 & & \\
\hline & PL & $9,67 \pm 1,96$ & $9,85 \pm 2,18$ & 1,86 & $-0,35$ & & \\
\hline $\begin{array}{l}\text { Right Hand Grip } \\
\text { Strenoth [ko] }\end{array}$ & $\mathrm{RC}$ & $8,70 \pm 2,08$ & $8,67 \pm 2,71$ & $-0,35$ & 0,08 & 0,59 & 0,48 \\
\hline & $\mathrm{PL}+\mathrm{RC}$ & $9,50 \pm 2,32$ & $9,60 \pm 3,42$ & 1,05 & $-0,11$ & & \\
\hline & PL & $9,73 \pm 1,82$ & $9,54 \pm 2,21$ & $-1,96$ & $-1,96$ & & \\
\hline Left Hand Grip & $\mathrm{RC}$ & $8,40 \pm 2,22$ & $7,55 \pm 3,778$ & $-10,12$ & $-10,12$ & 1,70 & 1,06 \\
\hline & $\mathrm{PL}+\mathrm{RC}$ & $9,98 \pm 2,10$ & $9,15 \pm 3,49$ & $-8,32$ & $-8,32$ & & \\
\hline & PL & $510,40 \pm 138,82$ & $409,90 \pm 70,55$ & $-19,7$ & $-2,29^{*}$ & & \\
\hline Visual Reaction & $\mathrm{RC}$ & $488,70 \pm 112,00$ & $418,20 \pm 106,64$ & $-14,43$ & $-1,78$ & 0,01 & 0,23 \\
\hline & $\mathrm{PL}+\mathrm{RC}$ & $543,50 \pm 211,48$ & $420,80 \pm 67,41$ & $-22,58$ & 1,85 & & \\
\hline & PL & $557,30 \pm 288,35$ & $403,80 \pm 96,38$ & $-27,55$ & $-2,66^{*}$ & & \\
\hline Auditory Reaction & $\mathrm{RC}$ & $527,70 \pm 156,94$ & $341,00 \pm 82,84$ & $-35,38$ & $5,10^{*}$ & 0,62 & 1,21 \\
\hline & $\mathrm{PL}+\mathrm{RC}$ & $575,40 \pm 177,30$ & $395,70 \pm 112,32$ & $-31,24$ & $4,00^{*}$ & & \\
\hline & PL & $13,53 \pm 3,13$ & $11,36 \pm 1,21$ & $-16,04$ & $-2,91^{*}$ & & \\
\hline Plate Tapping & $\mathrm{RC}$ & $11,55 \pm 2,08$ & $10,99 \pm 2,39$ & $-4,85$ & 0,67 & 5,87 & 1,28 \\
\hline & $\mathrm{PL}+\mathrm{RC}$ & $10,38 \pm 1,29$ & $10,60 \pm 1,80$ & 2,11 & $-0,39$ & & \\
\hline Standing Broad & PL & $87,70 \pm 14,97$ & $94,50 \pm 16,40$ & 7,75 & $-2,27 *$ & & \\
\hline Jump & $\mathrm{RC}$ & $93,60 \pm 15,73$ & $100,80 \pm 8,24$ & 7,69 & $-1,79$ & 0,71 & 0,24 \\
\hline$[\mathrm{cm}]$ & $\mathrm{PL}+\mathrm{RC}$ & $95,10 \pm 13,14$ & $96,60 \pm 21,55$ & 1,57 & $-0,35$ & & \\
\hline Sit-Up Test For 30 & PL & $14,60 \pm 3,83^{b}$ & $16,80 \pm 5,05$ & 15,06 & $-2,90^{*}$ & & \\
\hline Seconds & $\mathrm{RC}$ & $11,80 \pm 3,67^{\mathrm{a}}$ & $16,10 \pm 4,25$ & 36,44 & $-3,24 *$ & 3,69 & 0,41 \\
\hline [reps] & $\mathrm{PL}+\mathrm{RC}$ & $9,70 \pm 4,57^{\mathrm{a}}$ & $16,60 \pm 5,56$ & 71,13 & $-2,81^{*}$ & & \\
\hline & PL & $24,04 \pm 2,28$ & $25,31 \pm 2,00$ & 5,28 & $-2,05^{*}$ & & \\
\hline $10 \times 5 \mathrm{~m}$ & $\mathrm{RC}$ & $23,20 \pm 1,36$ & $24,83 \pm 2,21$ & 7,02 & $-2,18$ & 0,59 & 1,01 \\
\hline & $\mathrm{PL}+\mathrm{RC}$ & $23,22 \pm 1,15$ & $23,96 \pm 2,24$ & 3,18 & $-0,90$ & & \\
\hline & PL & $25,60 \pm 2,87$ & $29,30 \pm 3,33$ & 14,45 & $-4,52 *$ & & \\
\hline Sit and Reach & $\mathrm{RC}$ & $28,70 \pm 3,36$ & $31,10 \pm 3,98$ & 8,36 & $-2,37^{*}$ & 3,25 & 3,44 \\
\hline & $\mathrm{PL}+\mathrm{RC}$ & $27,40 \pm 5,48$ & $32,40 \pm 3,43$ & 18,24 & $-3,59 *$ & & \\
\hline & PL & $4,10 \pm 2,38$ & $5,69 \pm 2,13$ & 38,78 & $-2,64 *$ & & \\
\hline Bent Arm Hang & $\mathrm{RC}$ & $6,19 \pm 3,39$ & $7,04 \pm 5,11$ & 13,73 & $-0,49$ & 1,02 & 0,25 \\
\hline & $\mathrm{PL}+\mathrm{RC}$ & $4,66 \pm 4,12 \pm$ & $6,26 \pm 4,03$ & 34,33 & $-1,90$ & & \\
\hline Flamingo Balance & $\mathrm{PL}$ & $18,20 \pm 9,96$ & $18,70 \pm 7,73$ & 2,74 & $-0,98$ & & \\
\hline Test & $\mathrm{RC}$ & $15,30 \pm 9,01$ & $15,10 \pm 8,26$ & $-1,31$ & 0,00 & 1,67 & 1,84 \\
\hline [reps] & $\mathrm{PL}+\mathrm{RC}$ & $14,70 \pm 10,68$ & $19,20 \pm 8,32$ & 30,61 & $-0,41$ & & \\
\hline & PL & $22,12 \pm 3,33$ & $22,47 \pm 3,41$ & 1,58 & $-0,67$ & & \\
\hline $\begin{array}{c}V \mathrm{O}_{2} \mathrm{Max} \\
\end{array}$ & $\mathrm{RC}$ & $21,25 \pm 3,45$ & $21,88 \pm 3,66$ & 2,96 & $-1,74$ & 0,18 & 0,12 \\
\hline & $\mathrm{PL}+\mathrm{RC}$ & $21,98 \pm 3,41$ & $21,78 \pm 2,93$ & $-0,91$ & 0,71 & & \\
\hline
\end{tabular}

$* \mathrm{p}<0,05$

In the study, pre training Body Mass Index (BMI) values are determined as $13,26 \pm 1,14 \mathrm{~kg} / \mathrm{cm}^{2}$ and post training values are determined as $14,05 \pm 1,07 \mathrm{~kg} / \mathrm{cm}^{2}$ in rhythmic gymnastics group, pre training BMI values are determined 
as $13,30 \pm 1,21 \mathrm{~kg} / \mathrm{cm}^{2}$ and post training values are determined as $12,62 \pm 4,60 \mathrm{~kg} / \mathrm{cm}^{2}$ in pilates group, also pre training BMI values are determined as $15,10 \pm 1,05 \mathrm{~kg} / \mathrm{cm}^{2}$ and post training values are determined as $15,03 \pm 1,37$ $\mathrm{kg} / \mathrm{cm}^{2}$ in pilates + rhythmic gymnastics group. Moselakgomo et al [2014] found BMI values of girls at the age of 9 as $13.7 \pm 2.13 \mathrm{~kg} / \mathrm{cm}^{2}$, at the age of 10 as $14.7 \pm$ $0.13 \mathrm{~kg} / \mathrm{cm}^{2}$, also Đorđević et al [2014] found BMI values of girls at the age of 7 as $16.04 \pm 1.2 \mathrm{~kg} / \mathrm{cm}^{2}[21,17]$.

In each of three training groups no significant change is determined in right-left hand grip in terms of the difference of training programs. In other words, no positive effect of trainings on muscle strength is determined. Gonzalez et al [2014] determined the hand grip strength of school children at the age of 7, as $10,8 \pm 2,5 \mathrm{~kg}$, Haslofça et al [2006] determined the hand grip strength of girls at the age of 7-8 as $10,45 \pm 2,31 \mathrm{~kg}$, Saygin et al [2006] determined the hand grip strength of girls at the age of $10-12$ as $17,69 \pm 4,77 \mathrm{~kg}$ $[22,15,13]$.

In the study, pre training visual reaction time is determined as $488,70 \pm 112,00 \mathrm{msec}$ and post training visual reaction time is determined as $418,20 \pm 106,64$ msec with a significant decrease for rhythmic gymnastics training group. In terms of auditory reaction time, a significant progress is determined between pre training and post training measurements in all three training groups $(p<0.05)$.

In terms of plate tapping times, only a significant decrease is determined in pilates training group, however no significant change is observed in other two groups. Đorđević et al [2014] determined plate tapping time of girls at the age of 7 as 27,09 $\pm 4,1 \mathrm{sec}$ and Gonzalez et al [2014] determined it as $21 \pm 3,6 \mathrm{sec}[18,22]$.

In terms of standing broad jump distances; pre-training value is determined as $93,60 \pm 15,73 \mathrm{~cm}$ and post training value is determined as $100,80 \pm 8,24 \mathrm{~cm}$ in rhythmic gymnastics training group, pre-training value is determined as $87,70 \pm 14,97 \mathrm{~cm}$ and post training value is determined as $94,50 \pm 16,40 \mathrm{~cm}$ in pilates training group, pre-training value is determined as $95,10 \pm 13,14 \mathrm{~cm}$ and post training value is determined as $96,60 \pm 21,55 \mathrm{~cm}$ in pilates + rhythmic gymnastics training group. Only the change in pilates training group is considered to be significant. Moselakgomo et al [2014] determined the standing broad jump distance of girls at the age of 9 as $117,3 \pm 20,13 \mathrm{~cm}$, Koç and Tekin [2011] determined the standing broad jump distance of two groups at the age of $7,05 \pm 0,22$ years and $7,09 \pm 0,30$ years as $117,73 \pm 8,88 \mathrm{~cm}$ vs $110,57 \pm 7,40 \mathrm{~cm}$ respectively [21,24].

In terms of 30 seconds sit-up test results; pre-training value is determined as $11,80 \pm 3,67$ reps and post training value is determined as $16,10 \pm 4,25$ reps in rhythmic gymnastics training group, pre-training value is determined as $14,60 \pm 3,83$ reps and post training value is determined as $16,80 \pm 5,05$ reps in pilates exercise training group, pretraining value is determined as $9,70 \pm 4,57$ reps and post training value is determined as $16,80 \pm 5,05$ reps in rhythmic gymnastics + pilates exercise training group. The increases in all three groups are statistically significant. Krska et al
[2014] determined the number of sit-up test for 30 seconds of the school children at the age of 7-8 as $14.13 \pm 2.91$ reps , Gonzalez et al [2014] determined it as 12,7 $\pm 5,9$ reps for the same age group. and Moselakgomo et al [2014] determined the number of sit-up test for 30 seconds of the girls at the age of 9 as 19,8 4,24 reps and for the girls at the age of 10 as $21.1 \pm 5.50$ reps. [25,22,21].

Fitt et al [1993] studied with 32 dancers consisted of 16 modern dancers and 16 ballets, randomly formed two groups of 16. The experimental group had a training of 30 minutes reformer- 2 and 60 minutes of mat work. Control group had their usual trainings. After 7 weeks, the dancers in the experimental group are determined to have significant improvements in terms of strength and flexibility [26]. Accordingly, flexibility and strength is considered to improve in a shorter time frame by pilates exercises accompanied by usual trainings in rhythmic gymnastics just like any other branches where these motoric parameters are of crucial importance.

In terms of $10 \times 5 \mathrm{~m}$ running time; pre training value is determined as $23,20 \pm 1,36 \mathrm{sec}$, post training value is determined as $24,83 \pm 2,21 \mathrm{sec}$ in rhythmic gymnastics training group, pre training value is determined as $24,04 \pm 2,28 \mathrm{sec}$ post training value is determined as $25,31 \pm 2,00 \mathrm{sec}(\mathrm{p}<0.05)$ in pilates exercise training group and pre training value is determined as $23,22 \pm 1,15 \mathrm{sec}$ post training value is determined as $23,96 \pm 2,24 \mathrm{sec}$ in rhythmic gymnastics + pilates exercise training group. Ciesla [2013] determined the value of $10 \times 5 \mathrm{~m}$ running time of girls at the age of 6 as 27,58 $\pm 3,72 \mathrm{sec}$, Đorđević et al [2014] determined the value of $10 \times 5 \mathrm{~m}$ running time of girls at the age of 7 as 18,98 $\pm 2,2 \mathrm{sec}$ Krska et al [2014] determined the value of $10 \times 5 \mathrm{~m}$ running time of school children at the age of $7-8$ as $27,09 \pm 2,18 \mathrm{sec}[27,17,25]$.

In terms of bent arm hang time, pre training value is determined as $6,19 \pm 3,39 \mathrm{sec}$, post training value is determined as $7,04 \pm 5,11 \mathrm{sec}$ in rhythmic gymnastics training group, pre training value is determined as $4,10 \pm 2,38 \mathrm{sec}$ post training value is determined as $5,69 \pm 2,13 \mathrm{sec}(\mathrm{p}<0.05)$; in pilates exercise training group and pre training value is determined as $4,66 \pm 4,12 \mathrm{sec}$ post training value is determined as $6,26 \pm 4,03 \mathrm{sec}$ in rhythmic gymnastics + pilates exercise training group. Fjortoft [2000] determined bent arm hang time values of children; at the age of 5 as $1,7 \pm 2,4 \mathrm{sec}$; at the age of 6 as as $2,11 \pm 2,3 \mathrm{sec}$,

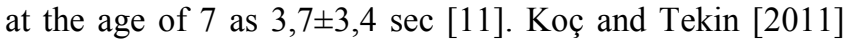
determined bent arm hang time values of children; at the age of $7,05 \pm 0,22$ years as $20,42 \pm 13,20$ years, at the age of $8,50 \pm 0,58$ years as $18,34 \pm 13,88 \mathrm{sec}$ and at the age of $9,33 \pm 0,48$ years as $25,66 \pm 16,90 \mathrm{sec}$ [24]. Strength increases through age, depending on body height, weight, levers of musculoskeletal system and increase in the mass of muscles in entire body [26]. Hence, arm force is to increase through trainings and age.

In the study, no significant difference is determined between the groups in terms of flamingo balance test results. However the most substantive increase is observed in the 
group having both training programs together. Johnson et al 82007] state that pilates exercise method has positive effects on development of balance. Pilates exercises are considered convenient for the branches where flexibility and balance are the fundamental elements of sportive performance [6].

Douada et al [2008] conducted a study named as physiological and anthropometric determinants in rhythmic gymnastics performance with the attendance of 34 gymnasts [two groups of 15 elite and 19 non elite gymnasts]. Some antropometric, physiological and physical measures are taken during the study and it is conducted that antropometric characterisics, aerobic power, flexibility and explosive power are important parameters for success in rhythmic gymnastics [4].

In terms of $\mathrm{VO}_{2}$ max values; pre training value is determined as $21,25 \pm 3,45 \mathrm{ml} . \mathrm{kg}$.min and post training value is determined as $21,88 \pm 3,66 \mathrm{ml} . \mathrm{kg}$.min in rhythmic gymnastics training group, pre training value is determined as $22,12 \pm 3,33 \mathrm{ml} . \mathrm{kg}$.min post training value is determined as $22,47 \pm 3,41 \mathrm{ml} . \mathrm{kg}$.min in pilates exercise training group and pre training value is determined as $21,98 \pm 3,41$ ml.kg.min post training value is determined as $21,78 \pm 2,93$ ml.kg.min in rhythmic gymnastics + pilates exercise training group. Gonzalez et al [2014] determined the $\mathrm{VO}_{2}$ max values of children at the age of 7 as $47,1 \pm 2,1$ ml.kg.min [22]. In another study conducted to measure aerobic endurance of rhythmic gymnasts, results of PWC170 test are determined as low values both in rhythmic gymnasts and the control group $[1,82 \pm 0,3 \mathrm{Watt} / \mathrm{kg}$ and 1,41 $\pm 0,2 \mathrm{Watt} / \mathrm{kg}$ respectively]. However the difference between two groups is stated as statistically significant $(\mathrm{U}=$ $66 ; \mathrm{p}<.05)[18]$.

In terms of sit and reach flexibility test values values; pre training value is determined as $28,70 \pm 3,36 \mathrm{~cm}$ and post training value is determined as $31,10 \pm 3,98$ in rhythmic gymnastics training group, pre training value is determined as $25,60 \pm 2,87 \mathrm{~cm}$ post training value is determined as $29,30 \pm 3,33 \mathrm{~cm}$ in pilates exercise training group and pre training value is determined as $27,40 \pm 5,48 \mathrm{~cm}$ and post training value is determined as was $32,40 \pm 3,43 \mathrm{~cm}$ in rhythmic gymnastics + pilates exercise training group. Zvezdan et al [2013] figured out the flexibility value of skiers at the age of 9-10, as 19,96 $\pm 1,27 \mathrm{~cm}$ [28]. Krska et al [2014] figured out the sit and reach flexibility value of school children at the age of $7-8$, as $22,41 \pm 2,91 \mathrm{~cm}$ [25]. Gonzales et al [2014] figured out the same value as $17,6 \pm 5,6 \mathrm{~cm}$ for 7 years old school children [22], Moselakgomo et al [2014] figured out the same value as $40,3 \pm 5,74 \mathrm{~cm}$ for 9 years old girls, and as $40,2 \pm 6,38 \mathrm{~cm}$ for 10 years old girls [21]. Parrot [1993] conducted a study and asked the questions such as: "Does aerobic conditioning and/or the pilates technique improve dance technique?" and "Do additional exercise protocols improve some dimensions of dance technique and not others?" He conducted his study with 18 university students aged between 19 and 30 who are having career education on modern dance. Dancers are divided into three groups of 6 . First group had pilates exercises of 80 minutes weekly in addition to their usual routine. Second group had aerobic dance training in addition to their usual routine, however third group continued to have their trainings usually. Judges have evaluated the two modern dance performances of every subject's blindly. In experimental group, statistically significant improvement observed in terms of alignment and clarity of movements and also in expressiveness of body. As a result, researchers concluded that pilates can be beneficial for dancers in order to improve technical and aesthetic performance [29]. Flexibility does not have an important role in any sports as it does in rhythmic gymnastics. Gymnasts need to have a preeminent flexibity in order to achieve a performance with wideness and elegance [30].

In parallel with the results of this study, Tudor et al [2014] conducted a study, by considering that gymnastics programs accompanied by pilates techniques will have a significant improvement on balance and coordinative capacity. They studied with two adult groups of 20 people. During 6 months, both groups had exercises with weights, elastic band and gymnastics ball. They came up with the conclusion that, learning pilates techniques have an effect on improving the quality of gymnastics programs and on improving balance and coordination [31].

\section{Conclusions}

In the study, significant differences observed in plate tapping, standing broad jump, 30 second sit-up test, $10 \times 5 \mathrm{~m}$ run, sit and reach flexibility and bent arm hang parameters after trainings at the pilates training group. The study also determined significant improvements after trainings in 30 second sit-up test and sit and reach flexibility parameters at rhythmic gymnastics training group and rhythmic gymnastics + pilates training group. In this study there were not any significant differences in visual and auditory reaction, plate tapping, standing broad jump and 10x5 m running among the pilates, rhythmic gymnastics and rhythmic gymnastics + pilates training groups. When results are analyzed, it can be said that rhythmic gymnastics training accompanied by pilates are more beneficial for the fundamental level girl gymnasts.

\section{Appendix}

\section{Rhythmic Gymnastics Training Program (90 mins) Beginning Session (10 mins) \\ General warmup (10 mins) \\ 5 tour running on gymnastics mattress sized $13 \mathrm{mx} 13 \mathrm{~m}$}

Warmup of head, shoulders, arms, waist, hips, legs, knees and ankles (two way circles, rhythmic movements to right and left)

\section{Master Session (70 mins)}

Specific warmup (25 mins)

Batmans on the floor and on the bar (Batmans on the floor: 
leg tossing with tensed (gergin) legs while lying down sideways on the elbow. Batmans on the bar: Leg tossing (forwards, backwards, sideways) with tensed legs by leaning on the gymnastics bar.

Static flexibility exercises on the ground (split, straddle) Elements with body rotations such as walkovers and rolls and/or full body waves performed either standing or on the floor

Tiptoe exercise (point-flex while sitting on the floor with tensed and closed legs, inward and outward circles)

Basic walking (15 mins)

Animal walking (bear, rabbit, duck, camel, crab, lame dog) Walking exercises (on the heels, on outsides and on the insides of the feet, on the releve, on the balls of the feet with front and side passe, on the releve with front and side passe+leg hold with 90 degrees, on the releve with holding leg; front with 90 degrees, sideways passé and arabesque backwards, walkings with forwards, backwards, sideways batmans)

Jumps (10 mins)

Variable combinations of jumps to form the basis (continuous jumps throughout the gymnastics band with tensed legs, twisted legs, open legs, small split, small straddle jumps, and combination of these jumps)

Technical jumps (vertical, cabriole, scissors, cossack, stag, split jumps)

Balances (10 min)

Different combination of balances which can be exercised on the balls or on the sole of the feet or on different parts of the body to form the basis of balance (Passé, balances with horizontal free leg to different directions, such as attitude and arabesque, Cossack, balances on the different parts of the body with support such as knee balance and cobra, dynamic balances with whole body wave, dynamic balances with leg movements both with and without support such as balances on elbow)

Rotations (10 mins)

Different combination of rotation exercises to form the basis of rotations (at least 360 degrees rotations on a part of the body, on the balls or on the sole of the feet such as split, bacwards split, illusion, passe, 90 degrees, attitude, arabesque, cossack)

\section{Finish Sessison (10 mins)}

Stafet race, tag play and stretching.

\section{Exercises Executed in Pilates Training Program}

1. Hundred

2. Roll Up

3. One Leg Circle

4. Rolling Like a Ball

5. Single Leg Stretch

6. Double Leg Stretch

7. Single Straight Leg Stretch

8. Double Straight Leg Lower and Lift

9. Criss Cross

10. Spine Stretch Forward

11. Open Leg Rocker-Pre

12. Corkscrew-I

13. Saw

14. Swan I-Neck Roll

15. Rest Position

16. Shoulder Bridge-Prep

17. Side Kick Series + Beats on Belly

18. Teaser One Leg

19. Teaser I

20. Swimming-Prep

21. Leg Pull Front-Support

22. Mermaid Stretch

23. Seal

24. Push Up Series

\begin{tabular}{|c|c|c|c|c|}
\hline$\frac{1}{\text { Hundred }}$ & $\frac{-5}{2}$ & One Leg Circle & Rolling Like a Ball & Single Leg Stretch \\
\hline Double Leg Stretch & Criss Cross & Spine Stretch Forward & Open Leg Rocker-Prep & \\
\hline Saw & SwanI-Neck Roll & Rest Position & Shoulder Bridge-Prep: & Side Kick Series \\
\hline Teaser One Leg & & Swimming-Prep & Leg Pull Front-Support & Mermaid Stretch \\
\hline Seal & Push Up Series & & & \\
\hline
\end{tabular}

Figure 1. Some exercises executed in of pilates training program 


\section{REFERENCES}

[1] M. Bobo-Arce, B. Mendez-Rial. Determinants of Competitive Performance in Rhythmic Gymnastics, Journal of Human Sport \& Exercise, Vol.8, No.3, 711-727, 2013.

[2] F. Altay, F. Doğan. Sportif Ritmik Cimnastik, Ünal Ofset, Ankara, 1996.

[3] A B. Santos, M E. Lemos, E. Lebre, L A. Carvalho. Active and Passive Lower Limb Flexibility in High Level Rhythmic Gymnastics, Science of Gymnastics Journal, Vol.7, No.2, 55-66, 2015.

[4] H T. Douda, A. G. Toubekis, A. A. Avloniti, S P. Tokmakidis. Physiological and Anthropometric Determinants of Rhythmic Gymnastics Performance, International Journal of Sports Physiology and Performance, Vol.3, No.1, 41-54, 2008.

[5] M. Mikalački, M. Emeše, N. Čokorilo, D. Korovljev, P J. R Montero. Analysis of The Effects of A Pilates Program on The Flexibility of Women, Physical Education and Sport Vol.10, No.4, Special Issue, 305- 309, 2012.

[6] D. Şimşek, H. Katırcı. The Influence of Pilates Exercises On Postural Stability And Sports Performance: A Systematic Review Of The Literature, Niğde University Journal of Physical Education And Sport Sciences,Vol.5, No.2, 58-70, 2011.

[7] D. Altıntaç, A. Pehlivan, F. Camlıüney. Pilates Egzersizlerinin Fiziksel Uygunluk Üzerine Etkileri, 9. Uluslararası Spor Bilimleri Kongresi, Muğla Üniversitesi, 541-543, 2006.

[8] K. Tamer. Sporda Fiziksel Fizyolojik Performansin Ölçülmesi ve Değerlendirilmesi, Bağırgan Yayınevi, Ankara, 2000.

[9] C. Şıpal. Eurofit Bedensel Yetenek Testleri El Kitabı, Roma, 1988.

[10] H C G. Kemper, W V. Mechelen. Physical Fitness Testing on Children: A European Perspective, Pediatric Exericses Science, Vol.8, 201-214, 1996.

[11] I. Fjortoft. Motor Fitness in Pre-Primary School Children: The Eurofit Motor Fitness Test Explored on 5-7 Year Old Children, Pediatric Exercises Science, Vol.12, No.4, 424436, 2000.

[12] M. Günay, K. Tamer, İ. Cicioğlu. Spor Fizyolojisi ve Performans Ölçümü, Baran Ofset, Ankara, 2006.

[13] İ. Şahiner, Ş S. Balcı. Çocuklarda Uygulanan Farklı OturUzan Esneklik Testlerinin Karşılaştırılması, Niğde Üniversitesi Beden Eğitimi ve Spor Bilimleri Dergisi, Cilt.4, No.1, 1-9, 2010.

[14] E. Haslofça, F. Haslofça, E. Kutlay. 7-8 Yaş Kız Çocuklarında Fiziksel Uygunluk Parametreleri Arasındaki İlişkinin İncelenmesi, 9. Uluslararası Spor Bilimleri Kongresi, Muğla Üniversitesi, 335-338, 2006.

[15] J.A. Davis. Direct Determination of Aerobic Power, In P.J. Maud \& C. Foster (Eds.), Physiological Assessment of
Human Fitness (2nd ed.) Champaign, IL: Human Kinetics, 9-18, 2006.

[16] E. Bağc1. 9-11 Yaş Grubu Artistik Cimnastikçi Bayan Sporcular İle Aynı Yaş Grubu Ritmik Cimnastikçilerin Bazı Fiziksel ve Kondisyonel ÖzelliklerininKarşılaştırılması, Yüksek Lisans Tezi, Gazi Üniversitesi Sağlık Bilimleri Enstitüsü, 2003.

[17] M M. Đorđević, S. Pantelić, R. Kostić, S. Uzunović. The Correlation between Anthropometric Characteristics and Motor Abilities in Seven-Year-Old Girls, Physical Education and Sport, Vol.12, No.3, 251-260, 2014.

[18] B M. Kankal, 9-12 Yaş Grubu Aerobik Cimnastik ve Ritmik Cimnastik Sporcularının Fiziksel, Fizyolojik ve Performans Özelliklerinin Karşılaştırılması, Yüksek Lisans Tezi, Ankara Üniversitesi Sağlık Bilimleri Enstitüsü, 2008.

[19] N S. Koşar, H A. Demirel. Çocuk Sporcuların Fizyolojik Özelikleri, Acta Orthopaedica et Traumatologica Turcica, Vol. 38 Suppl, No.1, 1-15, 2004.

[20] Z. Elibol. Elit Ritmik Cimnastikçilerin Bazı Fiziksel Uygunluk ve Antropometrik Özelliklerin Değerlendirilmesi, Yüksek Lisans Tezi, Gazi Üniversitesi Sağlık Bilimleri Enstitüsü, 2000.

[21] V K. Moselakgomo, M A. Monyeki, A L. Toriola. Physical Activity, Body Composition and Physical Fitness Status of Primary School Children in Mpumalanga and Limpopo Provinces of South Africa, African Journal for Physical Health Education, Recreation and Dance, Vol.20, No.2, 343356, 2014.

[22] R. Gulias-Gonzalez, M. Sanchez-Lopez, A. Olivas-Bravo, M. Solera-Martinez, V. Martinez-Vizca'ıno. Physical fitness in Spanish Schoolchildren Aged 6-12 Years: Reference Values of The Battery EUROFIT and Associated Cardiovascular Risk, Journal of School Health, Vol.84, No. 10, 625-635, 2014.

[23] Ö. Saygın, S. Mengütay. Çocuklarda Fiziksel Aktivite ve Fiziksel Uygunluk Arasındaki İlişkinin Araştırılması, 9. Uluslararas1 Spor Bilimleri Kongresi, Muğla Ünivertsitesi, 371-373, 2006.

[24] H. Koç, A. Tekin. Beden Eğitimi Derslerinin Çocuklarda Seçilmiş Motorik Özellikler Üzerine Etkisi, Yüzüncü Yıl Üniversitesi Eğitim Fakültesi Dergisi, Cilts.8, Özel Say1, 917, 2011.

[25] P. Krska, J. Sedlacek, $A$. Hubinak, J. Kostial, M. Teplicancova. Gymnasium: Scientific Journal of Education, Sports, and Health, Vol.15, No. 2, 145-151, 2014.

[26] L M. Bernardo, E F. Nagle. Does Pilates Training Benefit Dancers? Journal of Dance Medicine and Science, Vo.10, No.1, 46-50, 2006.

[27] E. Ciesla. The Motor Development and Motor Skill of 6Year-Old Children from the Lublin Voivodship, Polish Journal of Sport and Tourism, Vol.20, No.2, 105-110, 2013.

[28] S. Zvezdan, S. Toplica, S. Nenad, J. Bojan. Differences in the Space of Motor Skills between Younger Male and Female Skiers, Physical Education and Sport, Vol.11, No.2, 147-156, 2013.

[29] A. Parrot. The Effects of Pilates Technique and Aerobic Conditioning on Dancers' Technique and Aesthetic, 
Kinesiology Medicine Dance, Vol.15, No.2, 45-64,1993.

[30] Konter. Sportif Ritmik Cimnastik, İnkılap Kitabevi, İstanbul, 1998.
[31] M. Hutchinson, 1. Tremain, J. Christiansen, J. Beitzel. Improving Leaping Ability in Elite Rhythmic Gymnasts. Medicine and Science in Sports Exercise, Vol.30, No.10, 1543-1547, 1998 